was allowed to consolidate the broken stone until it knit together to form a hard smooth surface impervious to water.

Macadam's methods differed from those of his contemporary Telford in two ways. He used no large blocks of stone as a foundation, because he maintained that a soft, elastic base which 'gave' a little would withstand heavy traffic much better. Neither would he have gravel or similar binding material in the surface layer, as Telford recommended.

Many roads which are nowadays described as 'macadam' are not macadam at all, according to the strict letter of the method described by the inventor of the process. They are laid with small material mixed with the larger pieces to act as a binder, a thing which Macadam absolutely forbade. His was a counsel of perfection, however, because unless the stones have the correct shape they will not bed down without admixture to form the regular mosaic characteristic of the true macadam.

Macadam's energy and persistence gradually bore fruit. The enormous improvement of the roads under his jurisdiction became generally known, and in 1823 he described his methods in evidence before a committee of the House of Commons. As a result, macadam replaced the granite causeways in many of London's important streets, in spite of the dismal predictions of people who opposed the change. Southey wrote that "macadamising the streets of London is likely to prove quackadamising", but that opinion was probably due more to his admiration for Telford than to any critical examination of the available facts.

Before recognition came to him, Macadam spent $£ 5,000$ out of his own pocket in developing his method, and travelled 30,000 miles to help officials and others who asked for his advice. The greatly increased speed of the coaches gives a striking proof of the soundness of his ideas, which made English roads the best in the world. Whereas the journey from London to Edinburgh used to take 14-16 days, the time had fallen by 1830 to 40 hours-a remarkable improvement. In recognition of his services, Parliament voted him $£ 10,000$, which he accepted, and he was offered a knighthood, which he declined. His son accepted the honour in his stead.

Macadam described his researches in his memoir : "A Practical Essay on the Scientific Repair and Preservation of Public Roads", published in 1819. Other works on the same subject appeared from his pen. He died on November 26,1836 , in his eightyfirst year at Moffat, near Telford's birthplace, on one of his frequent visits to the scenes of his boyhood.

Although many of Macadam's roads remain, they can no longer compete with the concrete 'speedways' of the modern era. They belong to a quieter age, when the horse jogged leisurely along the country lanes, and the passengers had time to notice the honeysuckle in the hedgerows. Yet they were our roads for more than a century, and it will be many years before the man who made them is forgotten.

\title{
Obituary
}

Prof. W. A. Parks, F.R.S.

$\mathrm{T}$ HE death occurred in Toronto, on October 3, of Prof. W. A. Parks, professor of geology in the University of Toronto. William Arthur Parks was born in Hamilton, Ontario, in 1868, and educated in Bowmanville High School and the University of Toronto. With his university he was to be associated for the rest of his life, and his career is a long list of ascending responsibilities. He graduated B.A. in 1892 , became a 'fellow of geology' in the following year, and was in turn instructor, lecturer and, in 1905, associate professor. In 1913 he was appointed director of the newly constituted Royal Ontario Museum of Palæontology, an institution which has greatly developed under his guidance. From 1916 until 1922, Dr. Parks was professor of palæontology and in the latter year he was promoted to the full chair of geology.

With his large department and his museum ever increasing in importance, Prof. Parks was fully occupied, yet he found time to conduct expeditions in northern Ontario and to undertake research in various directions. He was particularly interested in American Stromatoporoidea and also published a series of papers on the geology and palæontology of the Toronto distriet. He was also interested in, and published a comprehensive account of, the building and ornamental stones of Canada.

In his later years, attracted by the rich material in his museum, Prof. Parks turned to vertebrate palæontology and described many new genera and species of highly interesting dinosaurs. Despite these numerous activities he found time for service on outside bodies. He was president of Section C (Geology) of the British Association at Southampton in 1925, president of the Royal Society of Canada, 1925-26, president of the Palæontological Society of America, 1926-27, and president of the Royal Canadian Institute, 1928-29. His talents were recognized in Great Britain by his election to the Royal Society in 1934.

For the last few years, Prof. Parks had patiently borne much serious illness, but his interest in his 
science and in his newly and greatly extended museum was not diminished. His death is a great loss to Canadian geology, and the sympathy of all who knew his pleasant and kindly personality will go out to his widow and his son.

W. E. S.

\section{Mr. D. A. Jones}

Mr. Daniel ANGell Jones, formerly secretary and afterwards president of the British Bryological Society, who died at Bristol on October 6 in his seventy-sixth year, has long been a familiar figure among Welsh botanists. Whilst he was a schoolmaster at Harlech his assistance was often invoked by botanists interested in the flora of North Wales, especially of Merionethshire and Carnarvonshire. His keen eye and wonderful memory of detail, locality and habitat were well known to phanerogamic botanists, and in the detection of bryophytes and lichens he was unrivalled.

During the present century, the story of $\mathrm{Mr}$. Jones's life is largely linked up with that of the British Bryological Society. In 1895, a number of bryological enthusiasts formed the Moss Exchange Club. The main purpose was the exchange of specimens, but supplementary to this there was a desire to extend the knowledge of the distribution of bryophytes in Great Britain, as nothing in regard to this had been published since the issue of the second edition of the London Catalogue of British Mosses in 1881. In 1907, Mr. Jones took eharge as secretary of the beginner's section (Section II) and continued that work until 1922, when both sections became merged as the British Bryological Society. $\mathrm{He}$ became secretary of this and continued as such until the early part of this year, when he felt compelled to resign on account of ill-health. The knowledge of the vice-comital distribution of bryophytes increased rapidly, and this increase was greatly contributed to by Mr. Jones. The "Census Catalogues of British Hepatics" (1905) and of "Mosses" (1907) were followed by a second edition for "Hepaties" in 1913 and a third in 1926, and a second edition for "Mosses" in 1930.

During the Great War, Mr. Jones was a Government lecturer on agriculture in connexion with University College, Aberystwyth, for which the University of Wales bestowed on him the degree of M.Sc. in 1918. In 1925, he was elected an associate of the Linnean Society, of which he had previously been a fellow (18971912). He became vice-president of the British Bryological Society in 1933 and president in 1935 .

Jones was born in Liverpool on July 14, 1861, was a schoolmaster at Machynlleth for about six years, then at Harlech until he retired in 1924. After ten months spent in the study of bryophytes and lichens on the Continent, chiefly on the Riviera, he lived four years at Cheltenham, and the last five years of his life were spent at Bristol. His sense of humour, good fellowship and almost uncanny power of detecting rare or strange plants, rendered his presence amongst bryologists or hichenologists delightful and stimulating.

\section{Mr. Marius Maxwell}

By the untimely death at the age of forty-eight years of Marius Maxwell, which occurred on November 2 at Nice in an accident to an aeroplane which he was piloting, the British Museum (Natural History) and those interested in the study of natural history have lost a keen supporter.

Maxwell had lived a most adventurous life and the manner of his death will come as no surprise to those who knew him best. He was a very generous donor to the Natural History Museum, and many of the specimens which he collected in his early days in Java and northern India have found a permanent home in the National Collection. Chief amongst these may be mentioned the skull of the record Javan rhinoceros (Rhinoceros sondaicus) which carries a horn of $10 \frac{3}{4}$ in., and two skulls of the pygmy hog (Porcula salvanius) from Bhutan. Amongst his East African donations premier place must be given to the mounted head of a magnificent bull elephant which carries exceptionally long and slender tusks.

In 1911 Maxwell first visited Kenya Colony on a hunting trip between Nakuru and Lake Baringo, when the vast accumulation of game which he found in that country so impressed him that he determined to return later on a photographic expedition. The opportunity to re-visit East Africa did not come for another ten years, when in 1921 he conducted an expedition to the Masai Province and took some wonderful photographs of elephants and giraffes. One of the elephant photographs shows an old bull standing in the attitude of alarm with its ears widely spread; this photograph was taken at a range of 8 yards. It was there that he secured the amazing series of photographs of three elephants sauntering in a forest clearing, when he walked out into full view of the animals and proceeded to take about a dozen snapshots quite at close quarters. The giraffe photographs were some of the first photographs of galloping giraffe to be taken from a pursuing car, and Mr. Maxwell estimated the speed of these animals, when fully extended, as 28-32 miles an hour.

After a short trip to India on business, Maxwell returned to Mombasa in the spring of 1922 and went on another photographic expedition, first to Lake Natron and around the Tanganyika border in the south, and secondly up in the Northern Frontier Province along the Northern Guaso Nyiro. In the latter locality he obtained some excellent photographs of buffalo, elephant and hippopotamus. One close-up of a buffalo is especially awe-inspiring, as it shows the animal debating in its mind whether to charge or not. The elephant photographs taken in the region of the Lorian Swamp and at Abbas Wen are some of the most remarkable records ever made of these animals ; this is especially true of the group of advancing elephants which forms the frontispiece of Maxwell's monumental work entitled "Stalking Big Game with a Camera", published in 1924 by the Medici Society. This volume is very handsomely illustrated by a large number of photogravure reproductions of Maxwell's photographs, and will remain 